\title{
Method of Resolution Participatory and Creative Problem. A different approach to art teaching in the subject of
} E.V.T.

José Alberto Martins josealmartins@gmail.com CIEC, Universidade do Minho, Portugal

Reference

Martins, José Alberto; (2012) "Method of Resolution Participatory and Creative Problem. A different approach to art teaching in the subject of E.V.T.", p. 207-210. In: Barbosa, Helena; Quental, Joana [Eds]. Proceedings of the 2nd International Conference of Art, Illustration and Visual Culture in Infant and Primary Education. São Paulo: Blucher, 2015. ISSN 2318-695X, ISBN: 978-989-98185-0-7 DOI 10.5151/edupro-aivcipe-40

Os métodos de ensino das disciplinas ligadas às áreas artísticas do ensino básico, em Portugal, têm vindo a evoluir, no sentido de se explorarem novas abordagens neste domínio. A proposta de comunicação que se apresenta enquadra-se na temática: Infância e Educação: Projeto e Projetos. Partimos assim de um contexto real, o $2^{\circ}$ Ciclo do ensino básico, no qual se tentam desenvolver Práticas de Excelência de Ensino e Aprendizagem Artística e Tecnológica, numa escola rural do Alto Minho, pertencente ao Distrito de Braga. Este método de ensino tem início no processo de resolução de problemas (MRP), no qual se exploram conteúdos, competências e metas, no âmbito da disciplina de Educação Visual e Tecnológica (EVT).

Constata-se, neste contexto, que o MRP não se esgota enquanto método, tornando-se, por um lado, participativo, pois exige que a criança alargue o seu leque de ideias, através da cooperação com os seus pares. E por outro lado, criativo, na medida em que este constructo surge num ambiente controlado (a sala de aula), sem ameaça, no qual a criança tem possibilidade, também, de experimentar um vasto conjunto de situações de aprendizagem. Este projeto de intervenção realça a importância do desenho, da narrativa escrita e esquemas concetuais, elaborados pela criança, enquanto formas plurais de representação e comunicação de uma ideia, juntamente com a própria natureza da expressão plástica. Participação, Criatividade, Desenho; Resolução de problemas; Projeto.

Abstract

The teaching methods of the subjects related to the artistic areas of the basic teaching in Portugal have been developed with the purpose of exploring new approaches of this dimension. The communication proposal presented in this essay frames on the theme: Childhood and Education: Project and Projects. So, we intend to start upon a real context, the second term of the basic teaching, in which we try to develop Excellence Practices of artistic and technologic teaching and learning, in a rural school of Alto Minho, belonging to the district of Braga. This teaching method starts in the problems solution process (MRP), in which we explore contents, competencies and goals in the sphere of the Art subject (EVT).

So, in this context, we can infer that the MRP does not run out, since it is participative, on one hand, because it demands the child extend his amount of ideas through cooperation with his colleagues. On the other hand, the process we are referring to is creative, once this construction appears in a controlled environment (the classroom), without any kind of threat, where the child has also the possibility to try an enormous combination of learning situations. This intervention project emphasize the drawing importance, the written narrative and conceptual schemes, constructed by the child as plural ways of representation and communication of an idea together with the real nature of plastic expression. 


\section{Introduction}

This intervention program has being monitored in different stages. The first phase ended in 2009 (Martins, 2009) and consisted in the development of an alternative teaching and learning model of Art subject. The second phase was presented in 2011 , becoming known the way such intervention interferes in the development of the learning to learn competences (Martins, 2011). Finally, in this last phase we make public some results that were considered pertinent and make salient this educative program impact in significant learning and realization procedures in students of an Alto Minho school, of Vila Verde administrative subdivision, district of Braga, having as a start point the problems solution method (PSM).).

\section{Framing}

\section{Methodology}

\section{Brief presentation of the results}

The MRP/ PSM was well known by the teachers of the now extinct subject, Art (see the ministerial official communication number 17168/2011 of 23rd of December of 2011 and the new curricular organization) in which is clear that the working units were developed "normally around problems solution" (Ministerial official communication number 124/ME/91, of 31st of July) having as final goal, the acquisition by the child, of an average of general competences of fruition-contemplation; production-creation and reflection-interpretation.

Although, the most important in this communication is the explanation of how is it possible to organize, monitories, evaluate and reflect in its wide sense the PSM process can provoke an evolution, not only in teachers' practices (pedagogic pair), but also in students' learnings. So, it is convenient to emphasize that the PSM didn't ran out in its substance, in its linear way of making real an idea, but developed to other more complex solution structures, being in this dynamic the child creativity and the sharing construction of ideas (pairs and teachers), through a teaching and learning process of double mediation, well-founded in three learning supports: the affective aspects; the metacognitive and creative processes.

Based on these supports, we present the obtained results in the significant learnings and the operationalization ability of the PSM by students as a learning participative and creative method which pretends autonomy and increment of his auto regulation ability (Alencar, 2005; Amabile, 1996; Bahia, 2007; Coquet, 2000; Valadares \& Moreira, 2009; Zimmerman, 2000).

The methodology frames in investigation-action, conglobates a mix of procedures from a documental analysis till a results' comparison between the beginning and the end of this intervention that occurred the previous year (2010/11). Inside the documental analysis we built a counter of project tested and validated in earlier experiences (Martins, 2009, 311) in which students registers the whole route of learning (investigation, problem identification, solutions presentation, accomplishment and final reflection). To compare the initial and final results we ran over the t test to repeated samples, to $\alpha>0,05$ evoking SPSS (version 19), once we intended to analyze if there was or not increment as far as central tendency is concerned, in comparison to the significant learnings, using as comparative instrument of verification the conceptual maps (Novak \& Gowin, 1984, Valadares \& Moreira, 2009) and also in procedures used by students of the different stages of MRP, better saying, in the way they respected the phases described in the organization. As a complement of this procedure, it was made also the initial and final results analysis based on photographs. During this process, students started in large groups (4 to 5 elements) and finished it in pair work. Along this course, the evaluation process was shared with students; we raise the child's protagonism as an autopoietic.

Having in mind that the PSM has as main goal developing the students' autonomy in his learning process, we tried to understand how far that goal was substantiated comparing two important aspects referred previously: i) the acquisition of significant learnings; ii) the acquisition of planning and accomplishment of the work done in Art subject.

Table (4.1): shows the results obtained by the studied variables. The first one conglobates the figures related to the significant learning (SL) and the accomplishment procedures (AP) in the teachers' perspective. The second one represents the figures obtained by the conceptual 
Art, Illustration and Visual Culture in Infant and Primary Education
Arte, Ilustración y Cultura Visual en Educación Infantil y Primaria de Arte, Ilustracão e Cultura Visual na Educação Infantil e Primária
Tabela (4.1): Results between time 1 ( 11 ) and time 2 (T2) research with the use of the t test for independent variables.
Image (4.1): Illustration of some PSM moments maps, not only according to the students' perspective, but also through the teachers' point of view, namely those which is concerned to connection among concepts such as: i) the simple connections (SC); ii) Hierarchies (H); iii) Crossed Unions (CV); iv) and examples (EX). In the statistician context, we concluded that all variables that are being studied show a high level of significance except the accomplishment procedures. Therefore, we can say that the program gave sign of a good performance from time 1 to time 2 of this investigation. As far as procedures are concerned, we believe these have been assimilated very easily from the beginning by students, fact that may justify, in any way, the non statistical significance.

\begin{tabular}{|c|c|c|c|c|c|c|c|c|c|c|c|c|c|}
\hline & \multicolumn{12}{|c|}{ Leaming outcom $w$ and procedures for achioving signeficant } \\
\hline & & \multicolumn{6}{|c|}{ Drechetiors } & \multicolumn{6}{|c|}{ Inciependert Samales Ted } \\
\hline & & \multirow[t]{2}{*}{4} & \multirow[t]{2}{*}{ Mean } & \multicolumn{2}{|c|}{$\begin{array}{c}\text { 95: Conidence Irofival for } \\
\text { Mean }\end{array}$} & \multirow{2}{*}{ Mn } & \multirow[t]{2}{*}{ Max. } & \multirow[t]{2}{*}{1} & \multirow[t]{2}{*}{ dif } & \multirow{2}{*}{$\begin{array}{c}\text { Sif: } 602 \\
0, a s ?\end{array}$} & \multirow{2}{*}{$\begin{array}{l}\text { Sod Eror } \\
\text { Diffuraro }\end{array}$} & \multicolumn{2}{|c|}{$\begin{array}{c}\text { 95\% Confifence Interval } \\
\text { of toe DHererce }\end{array}$} \\
\hline & & & & Lowsor Dound & Upper Dound & & & & & & & Lomer & Upoer \\
\hline \multirow{2}{*}{$\begin{array}{l}\text { Sigrinuart } \\
\text { lesting }\end{array}$} & $\mathrm{TI}$ & $\infty$ & $6 \in, 4 J$ & $E J .11$ & 72.60 & 0.00 & 160 & \multirow{2}{*}{$-2,43$} & \multirow{2}{*}{118} & \multirow{2}{*}{$0,014^{*}$} & \multirow{2}{*}{3.80} & \multirow{2}{*}{$-17,32$} & \multirow{2}{*}{$-1,83$} \\
\hline & $\mathrm{T} 2$ & 31 & it. 02 & 71.41 & 0.63 & 32.73 & 100 & & & & & & \\
\hline \multirow{2}{*}{$\begin{array}{l}\text { scemeishrert } \\
\text { procedures }\end{array}$} & $T 1$ & 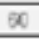 & 60,65 & 63.45 & 57.84 & 0.00 & 100 & \multirow{2}{*}{$-1,34$} & \multirow{2}{*}{119} & \multirow{2}{*}{; 82} & \multirow{2}{*}{4,70} & \multirow{2}{*}{$-16,62$} & \multirow{2}{*}{3,00} \\
\hline & $\mathrm{T} 2$ & 81 & 86,98 & E3.8? & 73,04 & 17,50 & 163 & & & & & & \\
\hline & & \multicolumn{12}{|c|}{ Toachers'Vlewpoint } \\
\hline & $\mathrm{TI}$ & 8 & 15.03 & 1255 & 17.61 & 0.00 & \begin{tabular}{|l|}
36 \\
\end{tabular} & & & & & & \\
\hline correcsons & $\mathrm{T} 2$ & 81 & 10.57 & 13.11 & 21.04 & 0.00 & 43 & 1.93 & 118 & $0,050^{-2}$ & 77 & 6.98 & 0,01 \\
\hline Hieranchier. & $\mathrm{TI}$ & $x$ & 16.92 & 15.15 & 10.60 & 0.00 & 30 & 2.37 & 118 & $0.918^{*}$ & 10 & 503 & 0.97 \\
\hline 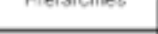 & $\mathrm{T} 2$ & 51 & 18.34 & 17.76 & 20.84 & 0.00 & 30 & 2,39 & 100 & 0,018 & , 10 & 急 & ${ }_{0}: 4$ \\
\hline Crum dUning & $\mathrm{TI}$ & 80 & 11.67 & 8,47 & 14.86 & 0.00 & 40 & 282 & 119 & $0.00 \sigma^{\circ}$ & $20 \mathrm{r}$ & $-9,80$ & $-1 / 28$ \\
\hline & 12 & 81 & 17,54 & 1487 & $x, 21$ & 0.00 & 40 & $-2,8 \pi$ & & & & & \\
\hline Formolats & $T 1$ & an & 1,07 & 0,55 & 1,89 & 0,00 & 8 & 0.57 & 119 & $0000^{\circ}$ & 269 & 340 & 0.99. \\
\hline Lampors & $\mathrm{T} 2$ & 61 & 3.28 & 2.14 & 4.42 & 0.00 & 20 & $-0,20$ & 118 & 0.900 & 0.00 & -3.40 & $-0,90$ \\
\hline & & & & & & Peint 0 & f view & $v$ of $s t$ & udents & & & & \\
\hline & & $\sqrt{4}$ & Mean & $\begin{array}{r}\text { A6se Coniden } \\
\text { Me }\end{array}$ & ne irtinal far & Min. & $M 2 x$ & $\mathrm{t}$ & df & Sils. $(a z$ & Std Eror & $\begin{array}{r}85 \% \text { Cont } \\
\text { of th }\end{array}$ & $\begin{array}{l}\text { nere Interval } \\
\text { Yererce }\end{array}$ \\
\hline & & & & Lowgr Bound & Upper Bound & & & & & & & Lo'ver & Upjer \\
\hline Siroe & $\frac{11}{T 2}$ & $\frac{Q}{21}$ & $\frac{1531}{216}$ & $\frac{1241}{7 \sqrt{71}}$ & $\frac{1 \mathrm{E}^{2}}{\mathrm{xh}}$ & \begin{tabular}{|l|}
000 \\
078
\end{tabular} & \begin{tabular}{|l|}
45 \\
70 \\
\end{tabular} & 4,00 & 116,87 & $0,000^{\circ}$ & 2,30 & $-13,74$ & $-4,64$ \\
\hline Hierarchies & $T 1$ & $\infty$ & 0.25 & $13 \pi$ & 10,74 & 0,00 & 35 & & 11367 & $0.001^{--}$ & 155 & 003 & 231 \\
\hline Hetarchies & $T_{2}$ & 31 & 21,14 & 1986 & 2402 & 0,00 & 42 & $-3,2,1$ & majej & $0001^{-2}$ & & $-0,00$ & $-2,31$ \\
\hline & $\mathrm{TI}$ & 80 & 13,23 & 9,12 & 17,44 & 0,00 & 103 & 277 & 120 & $0.006^{*}$ & & $-13,56$ & 2.27 \\
\hline srowsedomichs & 72 & 31 & 21,13 & 1728 & 25,09 & 0,00 & 60 & 2,7 & 120 & 0,000 & 2005 & $-19,200$ & -2.27 \\
\hline Examples & $\mathrm{TI}$ & 80 & 1,00 & $\frac{1,03}{203}$ & 2,52 & 0.00 & 11 & $-2,33$ & 120 & $0.019^{\circ}$ & 0.54 & $.2,34$ & $-0,22$ \\
\hline & $\mathrm{T} 2$ & 31 & 3,08 & 2,23 & 3,88 & 0.00 & 13 & & & & & & \\
\hline
\end{tabular}

This positive result in the context of the significant learnings and in a particular way, as far as interpretative competencies are concerned emphasizes, once more, the importance that Art subject had and also has in the cognitive children's development who attend the basic teaching. After all these assumptions we wonder if Art subject's contents won't be structural and essential part of the so "powerful" knowledge (Young 2007) so valorized on the other subjects, those that are called the nuclear ones.

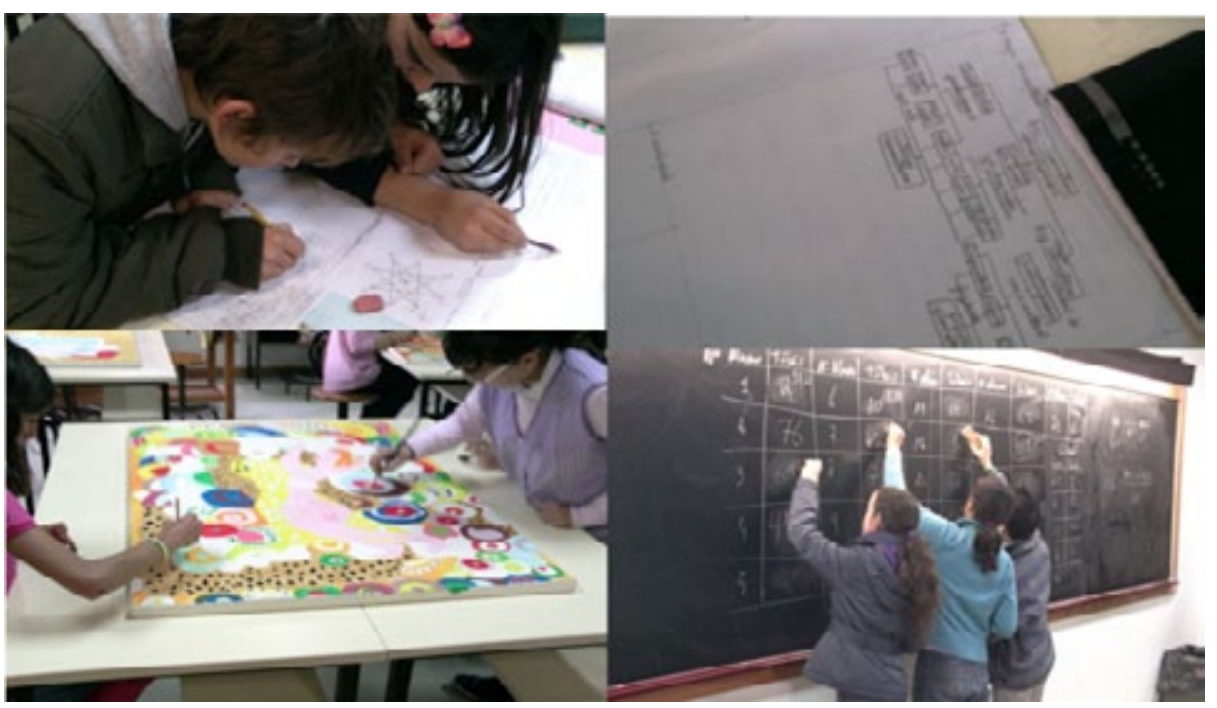


$2^{\text {nd }}$ International Conference Art. Illustration and Visual Culture in Infant and Primary Education
Congresso Internacional de Arte, Ilustração e Cultura Visual na Educação Infantil e Primária

Looking at the photographic composition of the image (4.1) we can give an explanation of this good performance.

First, this methodology allows that children regulate with much more efficacy the attention and memory mechanisms because it valorizes the child's ecology, allowing that each sensorial system work in an integrated way putting together the decision he makes, according to the time management to solve any kind of situation or problem. Second, such compromise is assumed by the working groups of students who can negotiate their own ideas with the other colleagues, creating this way a social learning environment, shared, without threat, that invites the child to risk and delineate his actions not by the immediate results, but by future perspectives, which encourage the close thought and consequently metacognition and creativity (Brown, 1987; Damásio, 2003; Vincent, 2010; Zimmerman, 2000).

\section{Bibliography}

Alencar, E. S. (2005). A gerência da criatividade. Abrindo as janelas para a criatividade pessoal e nas organizações. S. Paulo: Person Makron Books.

Amabile, T. M. (1996). Creativity in context. Colorado: Westview Press.

Bahia, S. (2007). Quadros que compõe a criatividade: Uma análise do teste de Torrance. Sobredotação, 7 , $161-175$.

Coquet, E. (2000). A Narrativa gráfica. Uma Estratégia de comunicação de crianças e de adultos. Braga: Bezerra Editora.

Damásio, A. (2003). O erro de Descartes. Emoção, Razão e Cérebro Humano. (23ª́d.). Mira-Sintra: Publicações Europa-América.

Gil, I. C. (2011). Literacia Visual. Estudos sobre a inquietude das imagens. Lisboa: Edições 70;

LeDoux, J. (2001). O Cérebro Emocional. Os mistérios alicerces da vida emocional. Rio de Janeiro: Editora Objetiva.

Leontiev, D. A. (2000). Funções da arte e educação estética. In J. P. Fróis. Educação Estética e Artística. Abordagvvens Transdisciplinares, (pp. 127-146). Lisboa: Fundação Calouste Gulbenkian.

Martins, J. A. L. G. (2009). Metacognição, Criatividade e Emoção na Educação Visual e Tecnológica: Contributos e orientações para a formação de alunos com sucesso. Tese de Doutoramento. Gualtar: Instituto de Educação da Universidade do Minho. Visualizado no dia 20 de Maio no endereço: http:// repositorium.sdum.uminho.pt/bitstream/1822/10671/1/TESE.pdf

Martins, J. A. L. G. (2011). Desenvolvendo Competências do Aprender a Aprender na disciplina de Educação Visual e Tecnológica. Atas do $23^{\circ}$ Encontro da APECV. Ensino das Artes Visuais. Identidade e Cultura no século XXI, (pp.416-444). APECV.

Novak, J. D.; Gowin, D. B.(1984). Aprender a aprender. Lisboa: Plátano Edições Técnicas.

Pereira, M. (2001). Inteligência e criatividade: Duas trajetórias alternativas para as crianças sobredotadas? Psicologia: Teoria, Investigação e Prática, 1, 171-188;

Sternberg, R. J. (2000). Inteligência de Sucesso. Como a inteligência prática e a criativa são determinantes para uma vida de sucesso. Lisboa: Esquilo.

Valares, J. A.; M. A. Moreira (2009). A Teoria da Aprendizagem Significativa. Coimbra: Edições Almedina.

Vincent, J. D. (2010). Viagem extraordinária ao centro do cérebro. Alfragide: Texto Editores.

Young, M. (2007). Para que servem as escolas? Educ. Soc., Campinas, Vol. 28, nº101, 1287-1302.

Zimmerman, B. J. (2000). Self-Efficacy: An Essential Motive to Learn. Contemporary Educational Psychology, 25(1), 89-91. 